Article

\title{
Hybrid Technology for DeNOxing by LNT-SCR System for Efficient Diesel Emission Control: Influence of Operation Parameters in $\mathrm{H}_{2} \mathrm{O}+\mathrm{CO}_{2}$ Atmosphere
}

\author{
Marina Cortés-Reyes*D, Concepción Herrera ${ }^{\mathbb{D}}$, María Ángeles Larrubia and Luis J. Alemany *(D) \\ Departamento de Ingeniería Química, Facultad de Ciencias, Campus de Teatinos, Universidad de Málaga, \\ E-29071 Málaga, Spain; concepcionhd@uma.es (C.H.); mavargas@uma.es (M.Á.L.) \\ * Correspondence: marinacr@uma.es (M.C.-R.); luijo@uma.es (L.J.A.); Tel.: +34-952-13-1919 (M.C.-R. \& L.J.A.)
}

Received: 17 January 2020; Accepted: 11 February 2020; Published: 14 February 2020

\begin{abstract}
The behavior and operation parameters were analyzed for the hybrid LNT-SCR (Lean $\mathrm{NO}_{x}$-Trap-Selective Catalytic Reduction) system with advanced catalyst formulations. Pt-Ba-K/ $/ \mathrm{Al}_{2} \mathrm{O}_{3}$ was used as an NSR ( $\mathrm{NO}_{\mathrm{x}}$ Storage and Reduction) or LNT catalyst effective in $\mathrm{NO}_{\mathrm{x}}$ and soot simultaneous removal whereas Cu-SAPO-34 with $2 \mathrm{wt}$ \% of copper inside the structure was the small pore zeolite employed as the SCR catalyst. Under alternating and cyclic wet conditions, feeding volumetric concentrations of 1000 ppm of $\mathrm{NO}, 3 \%$ of $\mathrm{O}_{2}, 1.5 \%$ of water, $0.3 \%$ of $\mathrm{CO}_{2}$, and $\mathrm{H}_{2}$ as a reductant, the $\mathrm{NO}_{\mathrm{x}}$-conversion values were above $95 \%$ and a complete mineralization to nitrogen was registered using $\theta \leq 3$ (20 s of regeneration) and a hydrogen content between 10,000 and 2000 ppm in the whole temperature range tested. An excess of hydrogen fed (above $1 \% \mathrm{v} / \mathrm{v}$ ) during the rich phase is unnecessary. In addition, in the low temperature range below $250{ }^{\circ} \mathrm{C}$, the effect is more noticeable due to the further ammonia production and its possible slip. These results open the way to the scale up of the coupled catalytic technologies for its use in real conditions while controlling the influence of the operation map.
\end{abstract}

Keywords: NSR-SCR hybrid catalysts; coupled aftertreatment technologies; DeNOxing; fixed double bed; $\mathrm{NO}_{\mathrm{x}}$ emission control

\section{Introduction}

The increase in nitrogen monoxide emissions with the use of new biofuels has been proven in a motor bench [1]. The way of driving modifies the production of $\mathrm{NO}_{\mathrm{x}}$ and efficient catalytic after-treatment technologies are required to reduce the levels below the limits imposed by the Euro 6 regulation. At present, $\mathrm{NO}_{x}$ Storage and Reduction (NSR) technology is the most efficient in the removal of nitrogen oxides from diesel exhaust gases. However, it is not enough to achieve zero emissions at the outlet of the vehicles, due to the formation of an $\mathrm{NH}_{3}$ slip that is strongly dependent on the catalyst formulation and the operation conditions [2-5]. The Selective Catalytic Reduction (SCR) process, which is based on the mineralization of $\mathrm{NO}_{x}$ to $\mathrm{N}_{2}$ and water with ammonia [6-9], requires the injection of an external reducing agent. Therefore, the coupling of SCR and NSR technologies is being widely studied to solve these drawbacks [10-15].

The idea consists of placing an SCR catalytic bed downstream of the NSR catalyst, so that the ammonia produced during the lean phase in the LNT-catalyst (Lean NO $\mathrm{N}_{\mathrm{x}}$ Traps) can be stored in the SCR catalyst and, then, it would react with the unconverted $\mathrm{NO}_{\mathrm{x}}$ in the oxidant phase, which increases the $\mathrm{NO}_{\mathrm{x}}$ conversion and the nitrogen selectivity. Commercially, the system was implemented in the Mercedes E320 Blue-Tech vehicle in 2007 [16]. The main advantages of this system compared to the 
single NSR catalytic bed are: the increase in $\mathrm{NO}_{x}$ conversion values, the ammonia-slip reduction, a wider operating temperature window, the improvement of the catalyst durability, and the reduction of unburned hydrocarbon production due to a reaction in the SCR catalyst $[10,17,18]$.

It is necessary to delve into the study of coupling technologies and their possible application in real conditions. Several authors have studied the coupling (double-bed) of standard $\mathrm{Pt}-\mathrm{Ba} / \mathrm{Al}_{2} \mathrm{O}_{3}$ and Fe-ZSM5 zeolite as an NSR and SCR catalyst, respectively, in powder form $[13,19,20]$ by detecting higher nitrogen production in the overall cycle. Similar results have been obtained by other authors when the $\mathrm{Cu}-\mathrm{ZSM}-5$ was placed downstream of a Pt-Rh-Ba/ $\mathrm{Al}_{2} \mathrm{O}_{3}[21]$ or when $\mathrm{Cu}-\mathrm{ZSM}-5$ is substituted for $\mathrm{Co} / \mathrm{Al}_{2} \mathrm{O}_{3}$ [22]. In the double-bed configuration, a higher level of nitrogen is detected in the lean phase when compared to a single bed due to the reaction of the nitrogen oxides with the ammonia that had been stored in the system in the previous phase.

The physical mixture of the catalysts produces a lower amount of nitrogen in the rich phase because one of the nitrogen production routes uses the ammonia as an intermediate and, with the zeolite being so close, the ammonia formed could be retained on the zeolite and, thus, the nitrogen formation would decrease. Therefore, the use of two independent catalysts without a physical mixture seems to be the most appropriate configuration [13]. Although other authors [23] have also proposed dual-layer monolithic catalysts, with both materials over the same wall, the higher conversions of $\mathrm{NO}_{\mathrm{x}}$ to nitrogen are, however, achieved using sequential monoliths.

As SCR catalysts, some authors [24] have developed materials based on modified alumina and prepared by a sol-gel method with the required acidic and redox properties by introducing metal ions such as cerium (for oxygen mobility), titanium, zirconium, and silica. Although, these materials are effective in the $\mathrm{NH}_{3}-\mathrm{SCR}$ reaction together with the $\mathrm{NH}_{3}-\mathrm{SCO}$ (Selective Catalytic Oxidation). The zeolite with the incorporation of copper is the most effective material that can be used in this technology up to now $[25,26]$. As far as copper zeolites are concerned, materials prepared by ion exchange or impregnation have been studied in granular and monolithic form $[12,23,27]$. In addition, large and small pore zeolites are used, and a higher hydrothermal stability and a wider operation temperature window were observed when the small pore zeolites were analysed. In all cases, the ammonia slip was negligible and $\mathrm{N}_{2} \mathrm{O}$ selectivity decreased with the use of double-bed configuration. Among them, SAPO-34 with a chabazite structure has been reported as one of the most active small pore zeolite used as an SCR catalytic bed related to a high substitution capacity by disperse and isolated copper species [28-30].

Regarding the operation parameters, the time of the reduction phase or the ratio between oxidation/reduction period times is another open key point in the behaviour of these materials [31-33]. A decrease in the rich pulse length provokes a reduction in the $\mathrm{NO}_{\mathrm{x}}$ removal efficiency because insufficient time was available for the completely regeneration of the catalysts $[22,34]$. These parameters influence the cost of the process.

It is important to establish the relationship between new improved formulations able to cushion $\mathrm{NO}_{\mathrm{x}}$ emissions in a wet atmosphere with the operation conditions of diesel engines for a suitable and real penetration of the zero emission technologies in the automotive sector.

Therefore, this work is focused on the study of the behaviour and the operation conditions of the sequential Pt-Ba- $\mathrm{K} / \mathrm{Al}_{2} \mathrm{O}_{3}$ and $\mathrm{Cu}-\mathrm{SAPO}-34$ catalysts, as an LNT-catalyst and SCR material, respectively, in powder form and in the presence of water and $\mathrm{CO}_{2}$, which has never been addressed in literature.

\section{Results and Discussion}

\subsection{Evaluation of $V_{N S R} / V_{S C R}$ Ratio in Dry He-Atmosphere}

Several cyclic experiments up to 50 cycles (1000 ppm of $\mathrm{NO}+3 \%$ of $\mathrm{O}_{2}$ and $2000 \mathrm{ppm}$ of $\mathrm{H}_{2}$ ) were carried out using transient response method (TRM) in an He-atmosphere (dry conditions) at each temperature $\left(200\right.$ or $350^{\circ} \mathrm{C}$ ) up to the stabilization of the catalyst behaviour. A low temperature value of the operation window of SCR and a representative temperature of the NSR catalysts were 
selected. Therefore, in Figure 1, the influence of $\mathrm{V}_{\mathrm{NSR}} / \mathrm{V}_{\mathrm{SCR}}$ in DeNOx performance expressed as $\mathrm{NO}_{\mathrm{x}}$ conversion and selectivity to $\mathrm{N}_{2}, \mathrm{NH}_{3}$, and $\mathrm{N}_{2} \mathrm{O}$ are presented.

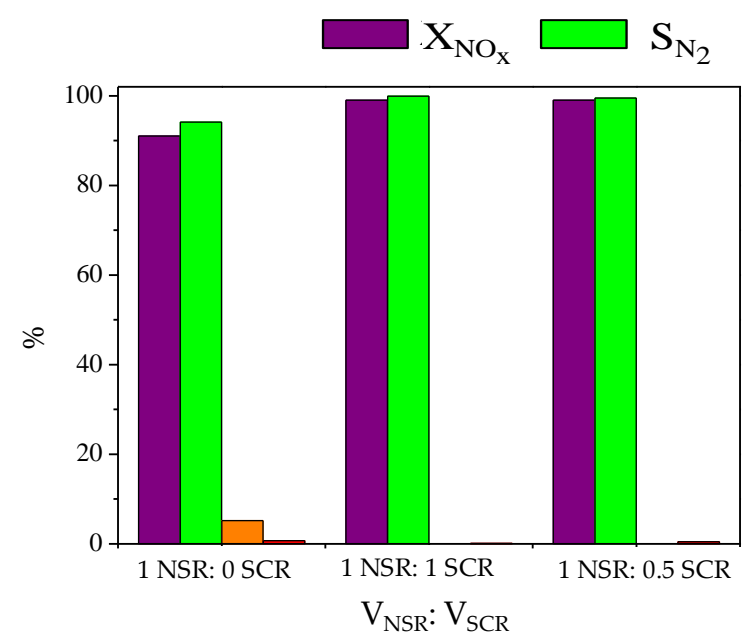

(a)

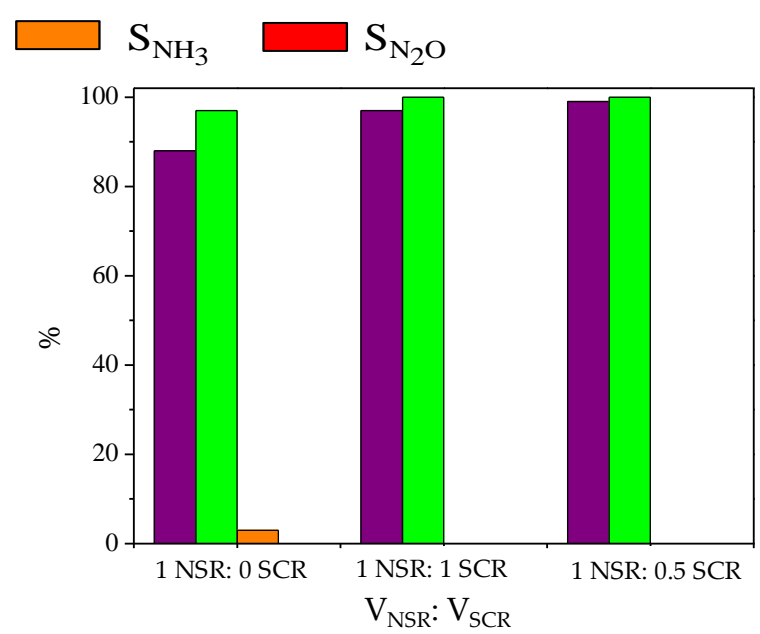

(b)

Figure 1. Conversion and selectivity values for different NSR/SCR volume ratios in experiments with NSR conditions (1000 ppm NO $+3 \% \mathrm{O}_{2} / 2000$ ppm $\mathrm{H}_{2}$ in $\mathrm{He}, 15-15 \mathrm{~min}$ ) at (a) $200{ }^{\circ} \mathrm{C}$ and (b) $350{ }^{\circ} \mathrm{C}$.

An increase in the $\mathrm{NO}_{\mathrm{x}}$ removed can be noticed compared to the values obtained with the single NSR bed-catalyst, Pt-Ba-K/ $/ \mathrm{Al}_{2} \mathrm{O}_{3}$, as can be verified in Reference [35], and was also observed and reported by other authors for both $\mathrm{Pt}-(\mathrm{Rh})-\mathrm{Ba} / \mathrm{Al}_{2} \mathrm{O}_{3}$ catalysts and $\mathrm{Cu}$-zeolites, such as ZSM5, BETA, or CHA $[10,22,27]$ working in cyclic conditions. For 1 NSR: 0 SCR configuration, i.e., with only a Pt-Ba-K/ $/ \mathrm{Al}_{2} \mathrm{O}_{3}$ catalyst, high $\mathrm{NO}_{x}$ conversion to $\mathrm{N}_{2}$ is detected with low ammonia production and a slight amount of $\mathrm{N}_{2} \mathrm{O}$ formation only at low temperatures. Ammonia was observed after nitrogen production in the middle of the rich phase, whereas an intense signal of $\mathrm{N}_{2} \mathrm{O}$ was detected at the beginning of the step with a maximum of $70 \mathrm{ppm}$ and was related to the low efficiency of the oxygen-covered $\mathrm{Pt}$ sites during the surface regeneration phase by $\mathrm{H}_{2}$, which prevents the $\mathrm{NO}$ dissociation and leads to $\mathrm{N}_{2} \mathrm{O}$ formation [36]. This does not take place at a high temperature since the Pt is kept in the reduced form [18]. The placing of the SCR catalyst after the NSR catalytic bed completely removes the ammonia production in all the volume proportions presented in this scenario. For 1 NSR: $1 \mathrm{SCR}$, besides the improvement in the $\mathrm{NO}_{\mathrm{x}}$ conversion and in the ammonia slip, a decrease in the $\mathrm{N}_{2} \mathrm{O}$, which is a highly polluting greenhouse gas, emission from $0.7 \%$ to $0.1 \%$ is also observed, as a consequence of the copper-zeolite bed-catalyst placed downstream. Nevertheless, the decrease of the SCR catalyst-volume, 1 NSR: $0.5 \mathrm{SCR}$, in spite of reducing the $\mathrm{NO}_{x}$ and $\mathrm{NH}_{3}$ production, negatively affects the $\mathrm{N}_{2} \mathrm{O}$ decrease, as other authors have observed for the coupling of an NSR catalyst based on noble metals and an Fe-zeolite [37] with commercial catalysts and similar space velocity values. A plausible explanation of this effect is that the increase in the NSR weight with respect to the SCR produces a higher amount of $\mathrm{N}_{2} \mathrm{O}$ and the SCR in this condition is not able to reduce all the gas produced. In this way, a reduction of N-containing products via the synergy of LNT-SCR coupled catalysts facilitated a major $\mathrm{NO}_{x}$ conversion. Considering the $\mathrm{NO}_{x}$ conversion, $\mathrm{NH}_{3}$ slip, and $\mathrm{N}_{2} \mathrm{O}$ production evaluated for three different NSR-SCR catalytic ratios in a dry He-atmosphere, the most suitable volume ratio of catalysts was 1:1 for the NSR-SCR hybrid system, since it keeps the $\mathrm{NO}_{\mathrm{x}}$ conversion, prevents the ammonia slip, and reduces the $\mathrm{N}_{2} \mathrm{O}$ emission.

\subsection{Influence of $\mathrm{H}_{2} \mathrm{O}$ and $\mathrm{CO}_{2}$ Presence over NSR-SCR Systems}

Hybrid LNT-SCR double-bed catalysts with $\mathrm{V}_{\mathrm{NSR}} / \mathrm{V}_{\mathrm{SCR}}=1 / 1$ was also studied in $\mathrm{CO}_{2}$ wet-atmosphere $\left(\mathrm{H}_{2} \mathrm{O}+\mathrm{CO}_{2}\right)$, and, although the NSR catalyst presents higher selectivity values, this 
is a more realistic condition that influences the deNOxing performance. In Figure 2, the profiles of the outlet gas distribution at $350{ }^{\circ} \mathrm{C}\left(1000 \mathrm{ppm}\right.$ of $\mathrm{NO}+3 \%$ of $\mathrm{O}_{2} / 2000 \mathrm{ppm}$ of $\left.\mathrm{H}_{2}\right)$ are represented for a cycle in which the catalysts are working in a stable way, in helium (Figure 2a), and water $+\mathrm{CO}_{2}$ (Figure 2b) atmospheres, respectively.

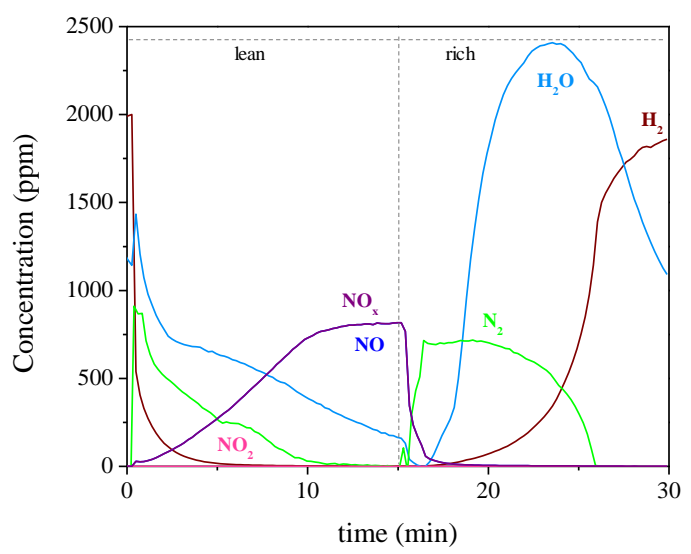

(a)

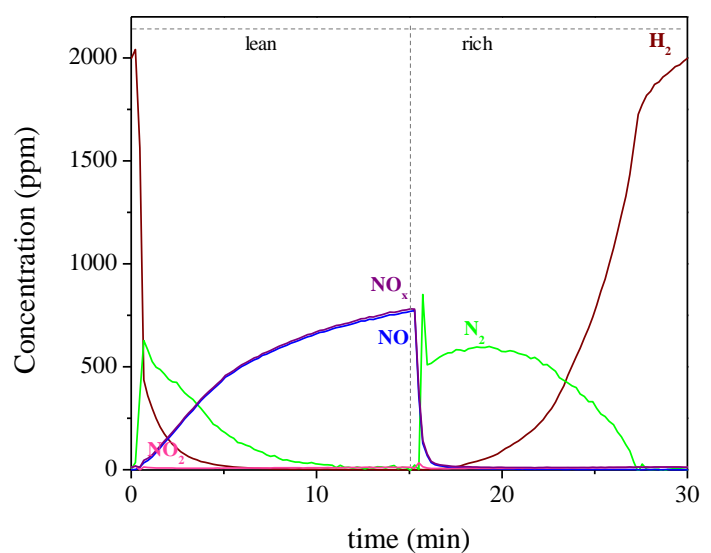

(b)

Figure 2. Storage-reduction stationary cycle (15-15 min) for Pt-Ba-K/ $/ \mathrm{Al}_{2} \mathrm{O}_{3}+2 \mathrm{Cu}-\mathrm{SAPO}-34$ at $350{ }^{\circ} \mathrm{C}$ in (a) $\mathrm{He}$ and (b) $\mathrm{H}_{2} \mathrm{O}+\mathrm{CO}_{2}$.

Under He atmosphere in the lean phase, the typical $\mathrm{NO}_{\mathrm{x}}$ saturation curve was appreciated, as a consequence of the storage of nitrites/nitrates, and the reaction with the adsorbed ammonia producing nitrogen and water, as is shown. $\mathrm{NO}$ and $\mathrm{NO}_{\mathrm{x}}$ curves overlapped since $\mathrm{NO}_{2}$ was not detected at the outlet due to the combination of the reaction with ammonia and the adsorption over both catalytic surfaces. In the rich phase, the profile of hydrogen is representative of the consumption by the reduction of the $\mathrm{NO}_{\mathrm{x}}$ adsorbed on the catalyst surface up to the entire regeneration of the catalyst with the corresponding nitrogen and water formation. However, during this phase (step), ammonia presence was undetectable due to the net storage in the SCR catalyst placed downstream. Moreover, the formation of $\mathrm{N}_{2} \mathrm{O}$ is almost insignificant due to the capacity of the copper modified-zeolite for the $\mathrm{N}_{2} \mathrm{O}$ decomposition, which other authors have reported with different copper-based materials [38-41] since copper ionic pairs or clusters and a chabazite structure are able to decompose $\mathrm{N}_{2} \mathrm{O}$.

On the other hand, in the presence of water and $\mathrm{CO}_{2}$ (Figure 2b), besides the same gas profiles, an additional consumption of $\mathrm{CO}_{2}$ was detected with $\mathrm{CO}$ formation (data not shown) due to the reverse reaction of the Water Gas Shift [14]. The obtained profiles both in dry and wet conditions in Helium and $1.5 \% \mathrm{H}_{2} \mathrm{O}+0.3 \% \mathrm{CO}_{2}$ presence, respectively, are similar to those reported [19] for the coupled $\mathrm{Pt}-\mathrm{Ba}$ and Fe-ZSM5 catalysts, in terms of nitrogen and water production and the shape and trend of the $\mathrm{NO}_{\mathrm{x}}$ and $\mathrm{H}_{2}$ saturation curves.

In Table 1, the representative activity parameters are shown and compared with those obtained for the single NSR catalytic bed. Similar trends were observed for both systems. However, the difference between the analyzed parameters should be pointed out. For all the experiments, as was expected, the amount of $\mathrm{NO}_{\mathrm{x}}$ removed increased with the incorporation of an SCR bed-downstream, with increased values similar to those previously reported $[13,19,20]$. Nevertheless, the effect depended on the temperature and the reaction atmosphere. 
Table 1. Reactivity data calculated during the storage-reduction of $\mathrm{NO}_{x}$ experiments from isothermal TRM profiles at $200{ }^{\circ} \mathrm{C}$ and $350{ }^{\circ} \mathrm{C}$ for Pt-Ba-K/Al $\mathrm{Al}_{2} \mathrm{O}_{3}$ (NSR) and Pt-Ba- $/ \mathrm{Al}_{2} \mathrm{O}_{3}+2 \mathrm{Cu}-\mathrm{SAPO}-34$ (NSR-SCR) systems.

\begin{tabular}{|c|c|c|c|c|c|c|c|}
\hline $\begin{array}{c}\text { Temperature } \\
\left({ }^{\circ} \mathrm{C}\right)\end{array}$ & Atmosphere & System & $\begin{array}{c}\text { Removed } \mathrm{NO}_{\mathrm{x}} \\
\left(10^{3} \mathrm{~mol} \mathrm{NO}_{\mathrm{x}} \mathrm{g}_{\mathrm{NSR}}{ }^{-1}\right)\end{array}$ & $\begin{array}{c}\mathrm{X}_{\mathrm{NOx}} \\
(\%)\end{array}$ & $\begin{array}{l}\mathrm{S}_{\mathrm{N} 2} \\
(\%)\end{array}$ & $\begin{array}{c}\mathrm{S}_{\mathrm{NH} 3} \\
(\%)\end{array}$ & $\begin{array}{r}\mathrm{S}_{\mathrm{N} 2 \mathrm{O}} \\
(\%)\end{array}$ \\
\hline \multirow{4}{*}{200} & \multirow{2}{*}{$\mathrm{He}$} & NSR & 0.39 & 91 & 94.1 & 5.2 & 0.7 \\
\hline & & NSR-SCR & 0.51 & 99 & 99.9 & 0 & 0.1 \\
\hline & \multirow{2}{*}{$\mathrm{H}_{2} \mathrm{O}+\mathrm{CO}_{2}$} & NSR & 0.24 & 83 & 90.5 & 9.5 & 0 \\
\hline & & NSR-SCR & 0.35 & 84 & 100 & 0 & 0 \\
\hline \multirow{4}{*}{350} & \multirow{2}{*}{$\mathrm{He}$} & NSR & 0.42 & 88 & 97 & 3 & 0 \\
\hline & & NSR-SCR & 0.53 & 91 & 100 & 0 & 0 \\
\hline & \multirow{2}{*}{$\mathrm{H}_{2} \mathrm{O}+\mathrm{CO}_{2}$} & NSR & 0.41 & 86 & 100 & 0 & 0 \\
\hline & & NSR-SCR & 0.52 & 92 & 100 & 0 & 0 \\
\hline
\end{tabular}

At low temperatures, the impact was more noticeable because of the higher ammonia production that can be used in the SCR process and the initially, more unfavourable conditions. The higher the amount of ammonia adsorbed, the more efficient the configuration since the SCR catalyst begins to work when a considerable amount of ammonia is stored in the catalyst. The conversion values also increased as shown by U. De La Torre et al. [12] who observed an increment in the presence of copper-exchanged zeolites. In this case, the initial values registered are high, almost $90 \%$, and the effect is less remarkable with increments below $10 \%$.

At $200{ }^{\circ} \mathrm{C}$ and in an $\mathrm{H}_{2} \mathrm{O}+\mathrm{CO}_{2}$ atmosphere, it seems that a balanced-cooperated effect causes a somewhat different behaviour. On the one hand, the Pt-Ba- $-\mathrm{K} / \mathrm{Al}_{2} \mathrm{O}_{3}$ catalyst in the presence of water and $\mathrm{CO}_{2}$ reduced the $\mathrm{NO}_{\mathrm{x}}$ adsorption capacity and conversion, which is in agreement with other authors [42,43], due to the interaction of the carbonates that compete with the nitrates for the same active sites [44]. The $\mathrm{NO}_{2}$ release is difficult in the presence of water and in the negative impact in the regeneration step when water and $\mathrm{CO}_{2}$ are co-fed because of the poisoning of the $\mathrm{Pt}$ sites by $\mathrm{CO}$ formation associated with a reverse water gas shift reaction [45]. On the other hand, the presence of water and $\mathrm{CO}_{2}$ in the SCR process over the $2 \mathrm{Cu}-\mathrm{SAPO}-34$ improves the performance in terms of conversion and selectivity values since it inhibits the ammonia oxidation and the nitrate decomposition and modifies the copper environment by obtaining more active species [46]. Therefore, in spite of the improvement provided by the SCR catalyst in these conditions, the negative effect of the reaction atmosphere over the NSR catalyst is stronger and, as a consequence, the conversion value is not considerably increased.

At $350^{\circ} \mathrm{C}$, the calculated parameters referred to the single NSR catalyst and obtained from the mathematical treatment of the curves represented in Figure 2, were high, with conversion and $\mathrm{N}_{2}$ selectivity values of around $90 \%$ and higher than $95 \%$, respectively, and the influence of placing an SCR catalyst downstream is less noteworthy. Nevertheless, conversion and the removed $\mathrm{NO}_{\mathrm{x}}$ increased due to the reduction with the adsorbed ammonia. The $\mathrm{CO}_{2}$ inhibition impact decreases with the temperature [47]. An increase in the conversion value can also be obtained because, in the reduction phase, the hydrogen can react with an initial ammonia formation and this ammonia could interact with the unconverted $\mathrm{NO}_{\mathrm{x}}$ forming nitrogen and water by selective catalytic reduction. L. Castoldi et al. [13] have observed the same effects caused by the presence of water and $\mathrm{CO}_{2}$ for the coupling of $\mathrm{Pt}-\mathrm{Ba} / \mathrm{Al}_{2} \mathrm{O}_{3}$ and Fe-ZSM5 with an increase in the selectivity and conversion with a rise in temperature or compared to the single NSR catalyst. However, the overall $\mathrm{NO}_{\mathrm{x}}$ conversion of the hybrid system presented in this case is higher than data found in the literature.

As far as selectivity is concerned, almost complete nitrogen selectivity was observed at 200 and $350{ }^{\circ} \mathrm{C}$. Thus, the double bed configuration allows the adsorption of the ammonia that is produced in the NSR-catalyst and the reaction with the nitrogen oxides of the following cycle. In addition, 
the decrease of the low amount of $\mathrm{N}_{2} \mathrm{O}$, only formed at a low temperature in dry conditions, was performed by the zeolite because that is able to decompose the $\mathrm{N}_{2} \mathrm{O}$ producing nitrogen.

\subsection{Influence of the Duration of Lean-Rich Cycles and the Concentration of $\mathrm{H}_{2}$}

The system with $\mathrm{V}_{\mathrm{NSR}} / \mathrm{V}_{\mathrm{SCR}}$ equal to one was selected due to the $\mathrm{NO}_{\mathrm{x}}$ conversion level reached, ammonia slip prevention, and $\mathrm{N}_{2} \mathrm{O}$ emission reduction. Besides temperature, the duration of lean-rich cycles and the concentration of the reducing agent (currently $\mathrm{H}_{2}$ ) in the respective lean and rich phases are very critical parameters [16]. A series of experiments were carried out in order to analyze the influence of these other operation parameters in the catalytic activity of the NSR-SCR system. For this purpose and with the intention of comparing the results with other authors, the dimensionless parameter $\theta$ has been defined as the ratio between the oxidation and reduction times and different values have been used, while the space velocity, the weight ratio between catalytic beds, and the feed composition were maintained. The optimization of lean and rich periods in order to ensure stable lean-rich cycles is essential for the engine operation. In addition, the concentration of the reducing agent $\left(\mathrm{H}_{2}\right)$ was also modified. All the operation parameters were summarized in Table 2.

Table 2. Flow conditions used in the TRM experiments over NSR-SCR systems.

\begin{tabular}{lcc}
\hline & Lean Phase & Rich Phase \\
\hline $\mathrm{NO}(\mathrm{ppm})$ & 1000 & - \\
$\mathrm{O}_{2}(\mathrm{v} / \mathrm{v} \%)$ & 3 & - \\
$\mathrm{H}_{2}(\mathrm{v} / \mathrm{v} \%)$ & - & $0.2,1,2.5$ \\
$\mathrm{H}_{2} \mathrm{O}(\mathrm{v} / \mathrm{v} \%)$ & 1.5 & 1.5 \\
$\mathrm{CO}_{2}(\mathrm{v} / \mathrm{v} \%)$ & 0.3 & 0.3 \\
$\mathrm{He}$ & Balance & Balance \\
$\mathrm{GHSV}\left(\mathrm{h}^{-1}\right)$ & $3 \times 10^{4}$ & $3 \times 10^{4}$ \\
Temperature $\left({ }^{\circ} \mathrm{C}\right)$ & 200,350 & 200,350 \\
$\theta=1$ & $20,60 \mathrm{~s}$ & $20,60 \mathrm{~s}$ \\
$\theta=3$ & $60 \mathrm{~s}$ & $20 \mathrm{~s}$ \\
$\theta=7.5$ & $150 \mathrm{~s}$ & $20 \mathrm{~s}$ \\
\hline \multicolumn{2}{r}{$\quad \theta=$ ratio between the oxidation and reduction times. }
\end{tabular}

In Figure 3, the profiles throughout the cycles for the experiments over the hybrid system $\left(\mathrm{V}_{\mathrm{NSR}} / \mathrm{V}_{\mathrm{SCR}}=1 @ 350{ }^{\circ} \mathrm{C}\right)$ when the parameter $\theta$ is set at 7.5 are shown, varying the amount of $\mathrm{H}_{2}$ as a reductant from 0.2 to $2.5 \mathrm{v} / \mathrm{v} \%$ and under an $\mathrm{H}_{2} \mathrm{O}+\mathrm{CO}_{2}$ atmosphere. As can be observed, the behavior in the storage and reduction of $\mathrm{NO}_{x}$ is completely dependent on the reductant concentration. At hydrogen contents close to the stoichiometric value (2000 ppm, Figure 3a), the $\mathrm{NO}_{\mathrm{x}}$ amount at the outlet increases throughout the cycles up to stabilization, which indicates that the amount of the reducing agent is not enough for the complete regeneration of the catalyst. This effect is similar to that observed in the transient experiments carried out in the thermobalance where the baseline increased at the end of the experiment due to an incomplete regeneration of the catalyst in the LNT condition with Pt-Ba-K/ $/ \mathrm{Al}_{2} \mathrm{O}_{3}$ catalyst, which we reported in a previous work [35]. Hydrogen was not detected in the outlet stream during the cycles due to the total consumption by reaction with the adsorbed nitrates. 

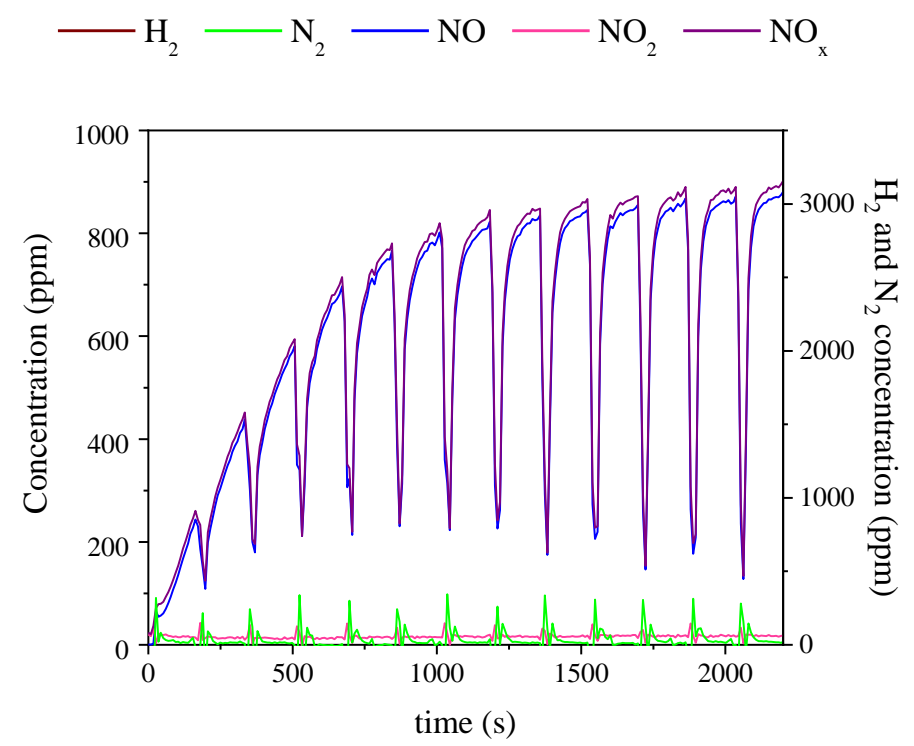

(a)

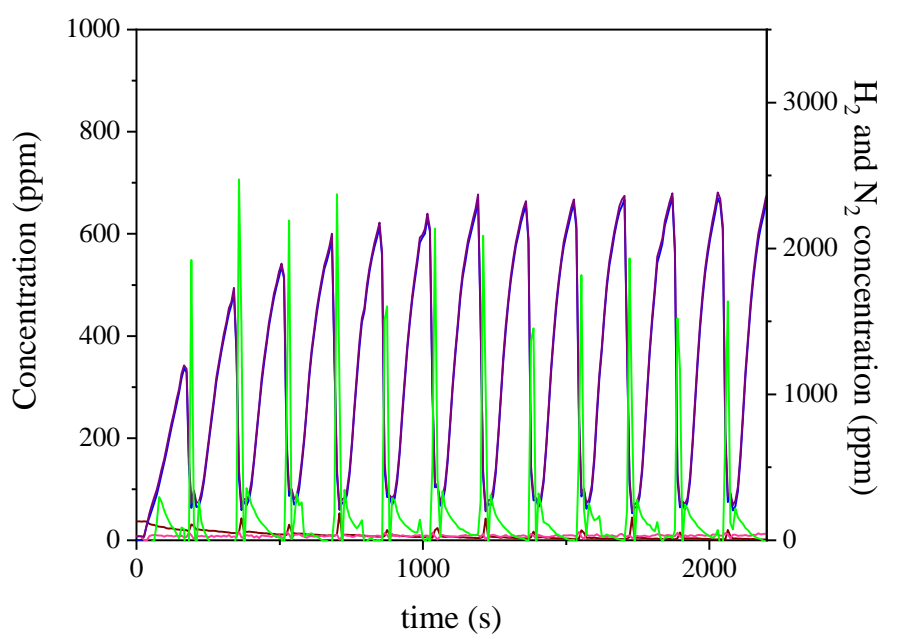

(b)

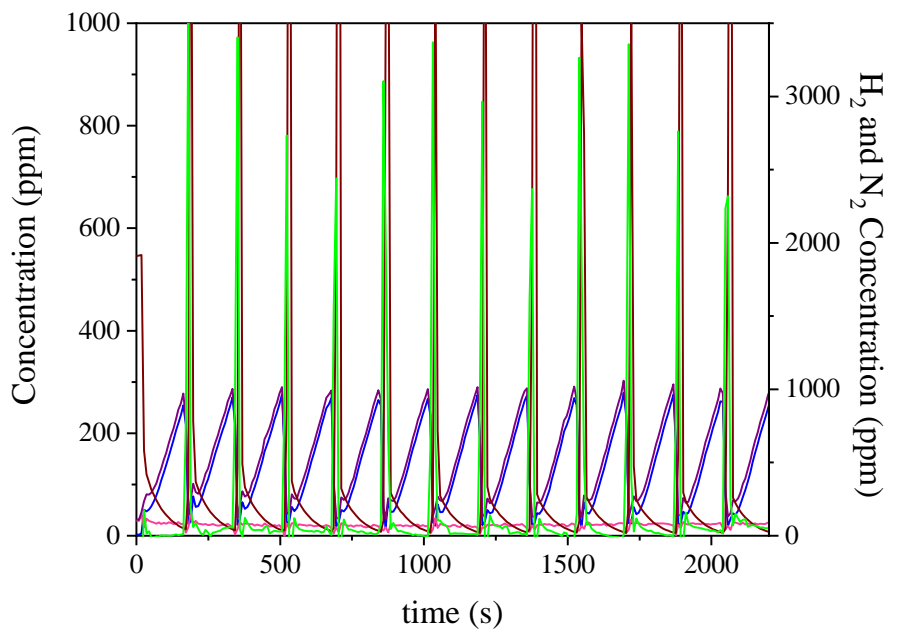

(c)

Figure 3. Storage-reduction cycles for Pt-Ba-K/Al $/ \mathrm{O}_{3}+2 \mathrm{Cu}-\mathrm{SAPO}-34\left(\mathrm{~V}_{\mathrm{NSR}} / \mathrm{V}_{\mathrm{SCR}}=1\right)$ at $350{ }^{\circ} \mathrm{C}$ with lean-rich periods of $150-20 \mathrm{~s}(\theta=7.5)$ with a hydrogen concentration of (a) $0.2,(\mathbf{b}) 1$, and (c) $2.5 \mathrm{v} / \mathrm{v} \%$ in $\mathrm{H}_{2} \mathrm{O}+\mathrm{CO}_{2}$. 
At hydrogen content of $1 \%$ (Figure 3b), the amount of $\mathrm{NO}_{\mathrm{x}}$ detected at the outlet was lower than in the previous experiments, even though it also increased with time, and hydrogen was not observed during the experiment, which means that, again, this concentration is not enough for the whole regeneration of the LNT-catalyst's surface.

For a reducing agent concentration of $2.5 \%$ (Figure 3c), the product distribution was completely different. The profile of $\mathrm{NO}_{\mathrm{x}}$ was identical for all the cycles performed, which means that the nitrates adsorbed onto the catalyst are fully removed by their reaction with the hydrogen in each cycle. In addition, $\mathrm{H}_{2}$ was detected during the rich step since an excess of the reductant was being fed into the reactor in these conditions. In terms of the product distribution and selectivity, nitrogen was the only compound observed at the outlet. Neither ammonia nor $\mathrm{N}_{2} \mathrm{O}$ were detected. However, the nitrogen production was higher as the hydrogen content increased, in consequence with the regeneration process explained above. In addition, if an overestimated amount of hydrogen is used, the production of ammonia would be too high and the SCR activity would decrease, which is the effect identical to the use of long, rich periods [14,48]. However, the $\mathrm{N}_{2} \mathrm{O}$ formation decreases with the amount of reductant agent [49].

In Table 3, the TRM-parameters calculated from the experiments with lean-rich time variations as a function of hydrogen percentage and temperature is summarized. $\mathrm{NO}_{\mathrm{x}}$ stored and $\mathrm{NO}_{\mathrm{x}}$ conversion values follow the trend described above from Figure 3. The influence of hydrogen concentration on the catalytic behaviour can be confirmed for the Pt-Ba-K/Al $\mathrm{Al}_{3}+\mathrm{Cu}-\mathrm{SAPO}-34$ mixture.

Table 3. TRM parameter values for the experiments performed over the Pt-Ba- $/ \mathrm{Al}_{2} \mathrm{O}_{3}+\mathrm{Cu}-\mathrm{SAPO}-34$ system with lean/rich time ratio variation as a function of the hydrogen percentage and the temperature.

\begin{tabular}{|c|c|c|c|c|c|}
\hline \multirow{2}{*}{$\begin{array}{c}\mathrm{H}_{2} \\
(\mathrm{ppm})\end{array}$} & \multirow{2}{*}{$\mathrm{T}\left({ }^{\circ} \mathrm{C}\right)$} & \multicolumn{2}{|c|}{$60 s-20 s(\theta=3)$} & \multicolumn{2}{|c|}{$150 \mathrm{~s}-20 \mathrm{~s}(\theta=7.5)$} \\
\hline & & $\mathrm{mmolNO}_{x} \cdot \mathrm{g}_{\mathrm{NSR}}{ }^{-1}$ & $\mathrm{X}_{\mathrm{NOx}}(\%)$ & $\mathrm{mmolNO}_{\mathrm{x}} \cdot \mathrm{g}_{\mathrm{NSR}}{ }^{-1}$ & $\mathrm{X}_{\text {NOx }}(\%)$ \\
\hline \multirow{2}{*}{2000} & 200 & 0.44 & 78.6 & 0.61 & 76.3 \\
\hline & 350 & 0.46 & 82.5 & 0.62 & 81.3 \\
\hline \multirow{2}{*}{10,000} & 200 & 0.69 & 97.3 & 1.2 & 94.3 \\
\hline & 350 & 0.71 & 99.3 & 1.3 & 95.6 \\
\hline \multirow{2}{*}{25,000} & 200 & 0.69 & 97.7 & 1.6 & 97.7 \\
\hline & 350 & 0.71 & 99.4 & 1.6 & 97.9 \\
\hline
\end{tabular}

The operation temperature was another parameter to control since the amount of nitrogen oxides that can be stored on the surface depends on the temperature as well as the selectivity. The improvement of the activity values at a low temperature is more noteworthy than at higher temperatures [32]. As can be seen, the influence of the reaction temperature was less noticeable than the hydrogen concentration. Nevertheless, the amount of nitrogen produced as well as the $\mathrm{NO}_{\mathrm{x}}$ at the outlet were slightly different depending on the temperature. Higher values of the activity parameters were obtained in the experiments at high temperatures, which occurs in the single NSR catalytic bed. However, the improvement of the coupling of both technologies in the hybrid system was more remarkable at low temperatures since the initial conditions were less favorable.

In Figure 4, the profiles throughout the cycles for the experiments over the hybrid system $\left(\mathrm{V}_{\mathrm{NSR}} / \mathrm{V}_{\mathrm{SCR}}=1\right.$, $\left.@ 350^{\circ} \mathrm{C}\right)$ when the parameter $\theta$ is set at 3 are shown, which varies the amount of $\mathrm{H}_{2}$ as a reductant from 2000 to $25,000 \mathrm{ppm}$ and under the $\mathrm{H}_{2} \mathrm{O}+\mathrm{CO}_{2}$ atmosphere. The decrease of the $\theta$ value below 3 modifies the behavior of the hybrid system. For the runs performed with $0.2 \%$ of hydrogen (Figure 4a), it is observed that the $\mathrm{NO}_{\mathrm{x}}$ concentration at the outlet increased throughout the cycles, but $1 \mathrm{v} / \mathrm{v} \%$ of $\mathrm{H}_{2}$ is enough for the complete reaction with the adsorbed nitrates. The conversion values obtained in these conditions (Table 3 ) indicated that total regeneration is possible when working with reducing agent content around five times the stoichiometric value, which is consistent with other authors [50] for higher flowrates and dual-layer systems. 

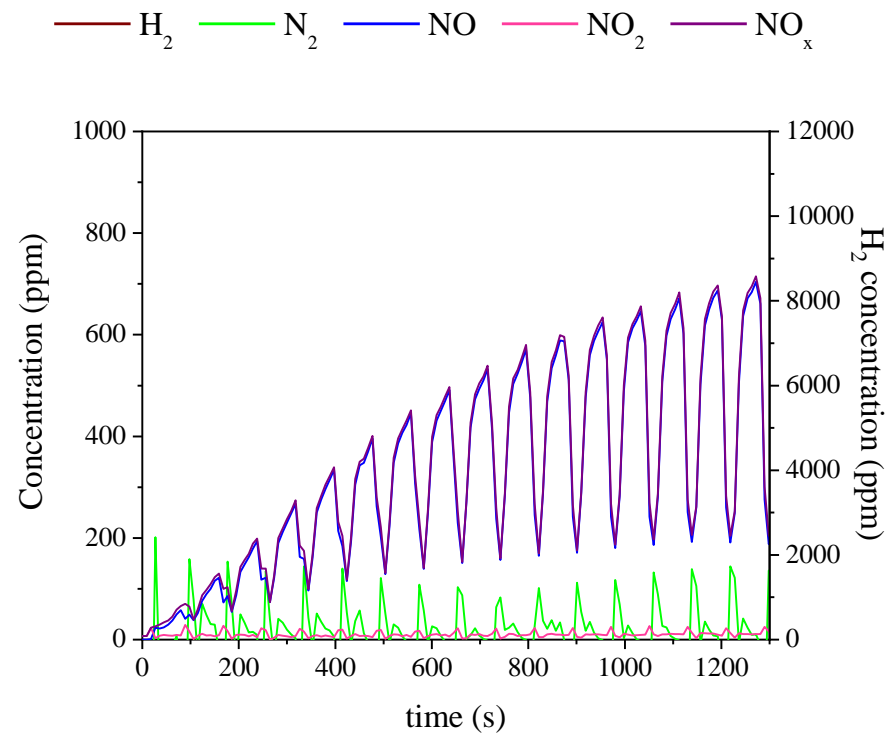

(a)

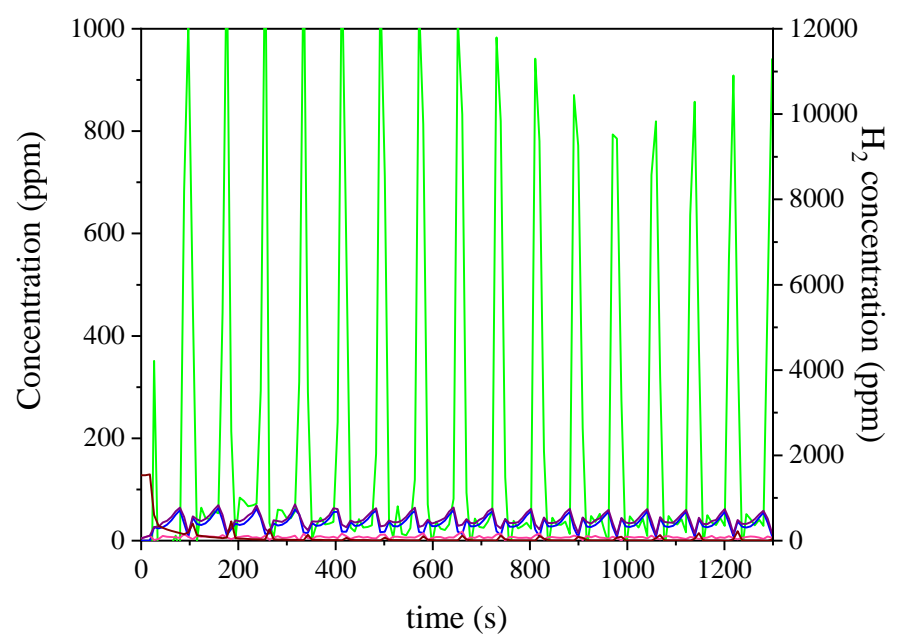

(b)

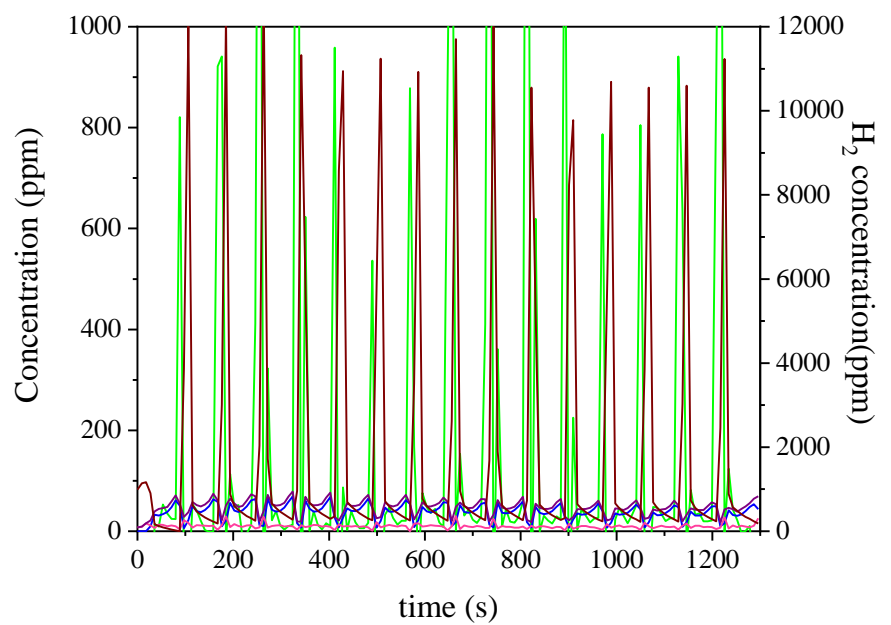

(c)

Figure 4. Storage-reduction cycles for Pt-Ba-K/ $/ \mathrm{Al}_{2} \mathrm{O}_{3}+2 \mathrm{Cu}-\mathrm{SAPO}-34\left(\mathrm{~V}_{\mathrm{NSR}} / \mathrm{V}_{\mathrm{SCR}}=1\right)$ at $350{ }^{\circ} \mathrm{C}$ with lean-rich periods of $60-20 \mathrm{~s}(\theta=3)$ with a hydrogen concentration of $(\mathbf{a}) 0.2$, (b) 1 , and (c) $2.5 \mathrm{v} / \mathrm{v} \%$ in $\mathrm{H}_{2} \mathrm{O}+\mathrm{CO}_{2}$. 
For the runs performed with $2.5 \mathrm{v} / \mathrm{v} \%$ of $\mathrm{H}_{2}$ (Figure 4c), the amount of $\mathrm{H}_{2}$ was overestimated for the regeneration of the catalyst and a minimum amount of $\mathrm{NO}_{\mathrm{x}}$ was detected (as can be observed in the inset). Zero emissions of nitrogen pollutant compounds were appreciated in these conditions. However, the amount of hydrogen at the outlet was high and this would imply the use of an unnecessary excess of reductant. Regarding the product distribution, nitrogen was the only product detected during the experiments, which was observed for higher values of $\theta$. Nevertheless, the amount of nitrogen for lower $\theta$ values was higher since the time of reduction was the same whereas the time of oxidation was lower.

From all the results presented, it can be assumed that, in the whole operation range, the amount of nitrogen oxides removed and the conversion and nitrogen selectivity values (Table 3 ) were higher than in the experiments with the single Pt-Ba- $-\mathrm{Al}_{2} \mathrm{O}_{3}$ catalyst. Particularly, they increased around $30 \%$ and $5 \%$, respectively. The amount of removed $\mathrm{NO}_{x}$ decreased with the reduction of hydrogen concentration, as a consequence of the incomplete regeneration of the catalyst explained above. The increase in the oxidation phase time caused an increment of almost double (between $38 \%$ and $100 \%$ ) the amount of removed $\mathrm{NO}_{x}$, at a constant removal rate. At high temperatures, the effect of the reductant content is less significant provided that it is higher than the stoichiometric concentration since the conversion values are above $90 \%$ and the nitrogen selectivity is high.

This means that such high amounts of hydrogen are not necessary, and the reducing agent consumption can be reduced as well as the chemical-equivalent input of a reducing agent. Nevertheless, although all the conditions are highly effective, hydrogen content around the stoichiometric seems to not be suitable for the removal of $\mathrm{NO}_{\mathrm{x}}$ in cyclic periods when the time of oxidation is higher than the reduction time. In addition, hydrogen levels below $0.8 \%$ were not recommendable to work with a $\theta$ value around 7 , due to the fact that the reductant supply would defected and, as consequence, the LNT-catalyst could not be completely regenerated, which decreases the $\mathrm{NO}_{x}$ removal efficiency [11], as has been verified. The $\theta$ decrease allows the regeneration of the catalyst, high $\mathrm{NO}_{\mathrm{x}}$ removal, and remarkable conversion values with less hydrogen in the whole operation range. Additionally, the reduction in $\theta$ implies the decrease in the necessary content of the reducing agent for the regeneration of the catalyst and obtaining high conversion values that prevent catalyst saturation. If the ratio between oxidant and reduction times is above 1 , the amount of hydrogen used in the regeneration phase has to be higher than the stoichiometric value. Nevertheless, as has been observed in all the experiments up to saturation with the same time for both phases, the regeneration of the catalysts was complete.

Therefore, it is worth considering the influence of the period time when the value of $\theta$ is set to 1. For that, experiments with the same time for both steps were carried out without modifying the $\theta$ value, and the profiles of the product distribution for the experiments with 60-60 s and 20-20 s using $0.2 \%$ and $1 \%$ of hydrogen in the $\mathrm{H}_{2} \mathrm{O}+\mathrm{CO}_{2}$ atmosphere, $\mathrm{V}_{\mathrm{NSR}} / \mathrm{V}_{\mathrm{SCR}}=1$, and $350{ }^{\circ} \mathrm{C}$, are represented in Figure 5.

As can be observed in Figure 5b,d, hydrogen concentrations above the stoichiometric, which is $1 \%$ in this case and higher than the exact content for the reduction of the nitrates. This would involve an unnecessary fuel overfeeding and cost. However, the total removal of the nitrogen oxides and the complete selectivity to nitrogen can be ensured from the first cycles. On the other hand, the use of $\mathrm{H}_{2}$ in the stoichiometric value presented a different behavior depending on the length of each period. In these conditions, the LNT-catalyst was being saturated slowly, even though the saturation time is modified by the period time. The saturation of the catalyst is reached before when longer times are used. Comparing Figure $5 \mathrm{a}, \mathrm{c}$, in the experiment with $60 \mathrm{~s}$ for each phase, the catalyst is saturated faster than using $20 \mathrm{~s}$ for each phase. This is due to the fact that the regeneration rate is different from the adsorption rate. The removed amount percentage and the adsorption rate are identical in each cycle because they depend on the temperature. 
$-\mathrm{H}_{2}-\mathrm{N}_{2}-\mathrm{NO}-\mathrm{NO}_{2}-\mathrm{NO}_{\mathrm{x}}$

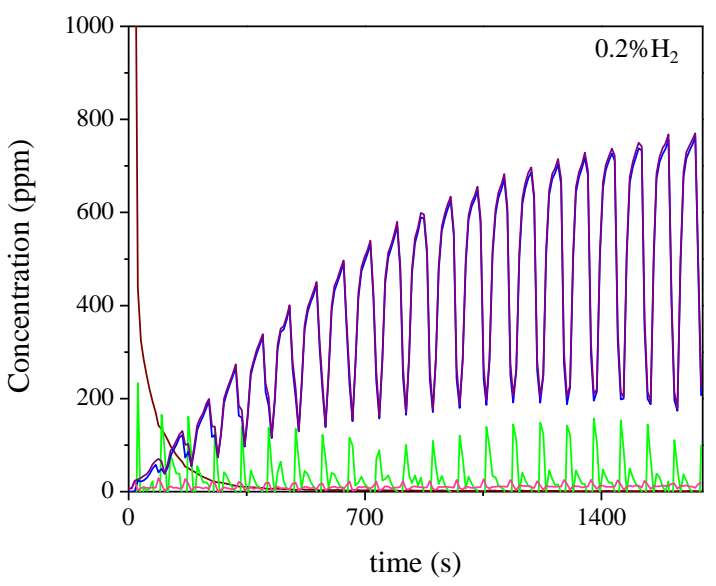

(a)

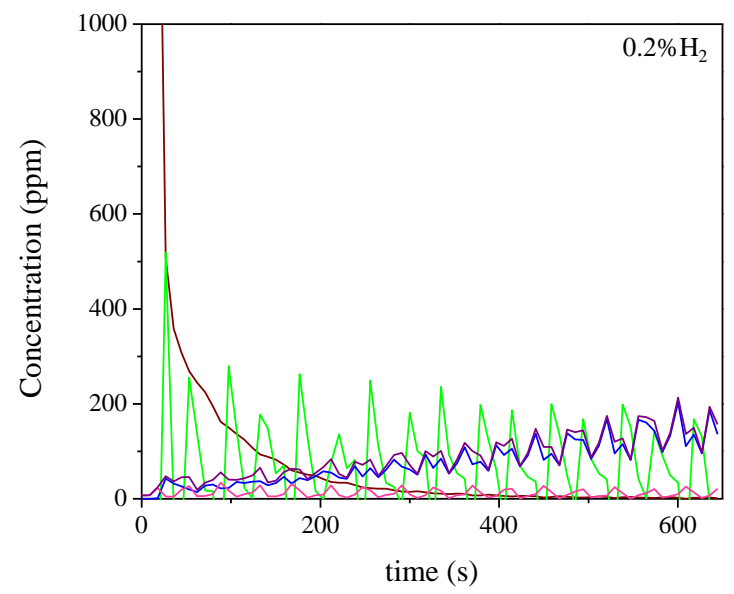

(c)

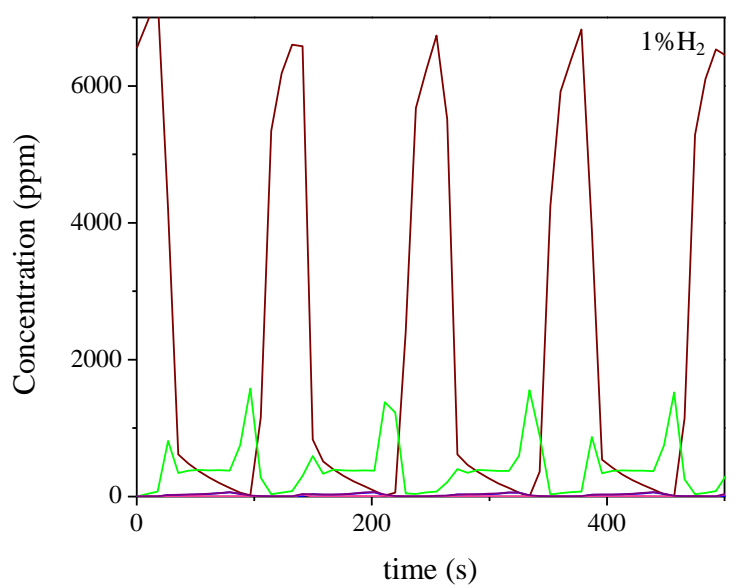

(b)

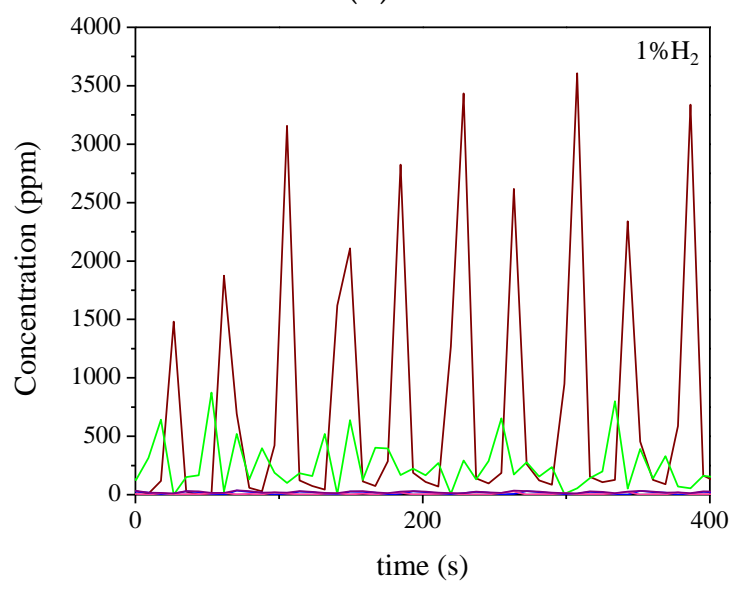

(d)

Figure 5. Storage-reduction cycles in $\mathrm{H}_{2} \mathrm{O}+\mathrm{CO}_{2}$ atmosphere for Pt-Ba- $\mathrm{K} / \mathrm{Al}_{2} \mathrm{O}_{3}+2 \mathrm{Cu}-\mathrm{SAPO}-34$ at $350{ }^{\circ} \mathrm{C}$ with lean-rich periods of $(\mathbf{a}, \mathbf{b}) 60-60 \mathrm{~s}$ and $(\mathbf{c}, \mathbf{d})$ 20-20 s with hydrogen concentration values of $0.2 \%$ and $1 \%$.

The changes detected were similar to the kinetic and geometric effects observed in the TG (thermogravimetric) experiments in a previous work [35] when the NSR catalyst was not completely regenerated and, consequently, $2000 \mathrm{ppm}$ of hydrogen is the exact stoichiometric value and the total reduction of the adsorbed species requires much longer time periods.

Therefore, stoichiometric hydrogen levels in over accumulation conditions cause the incomplete regeneration of a part of the catalyst and the saturation of the surface throughout the cycles. The operation conditions should ensure the availability of the catalyst for the following cycle. Therefore, hydrogen concentrations above 1.5 times the stoichiometric value are needed in order to obtain zero emissions and the regeneration of the catalyst when the $\theta$ value is around 1 .

Additional experiments were carried out in order to obtain a response surface modifying the parameters $X=f\left(\% \mathrm{H}_{2}, \theta\right)$. The distribution of the $\mathrm{NO}_{x}$ conversion data obtained after 20 cycles, while keeping a constant rich phase time of $20 \mathrm{~s}$, is represented in Figure 6. The operation regions are displayed with different colors, according to the conversion values, and isoconversion lines limit them. 


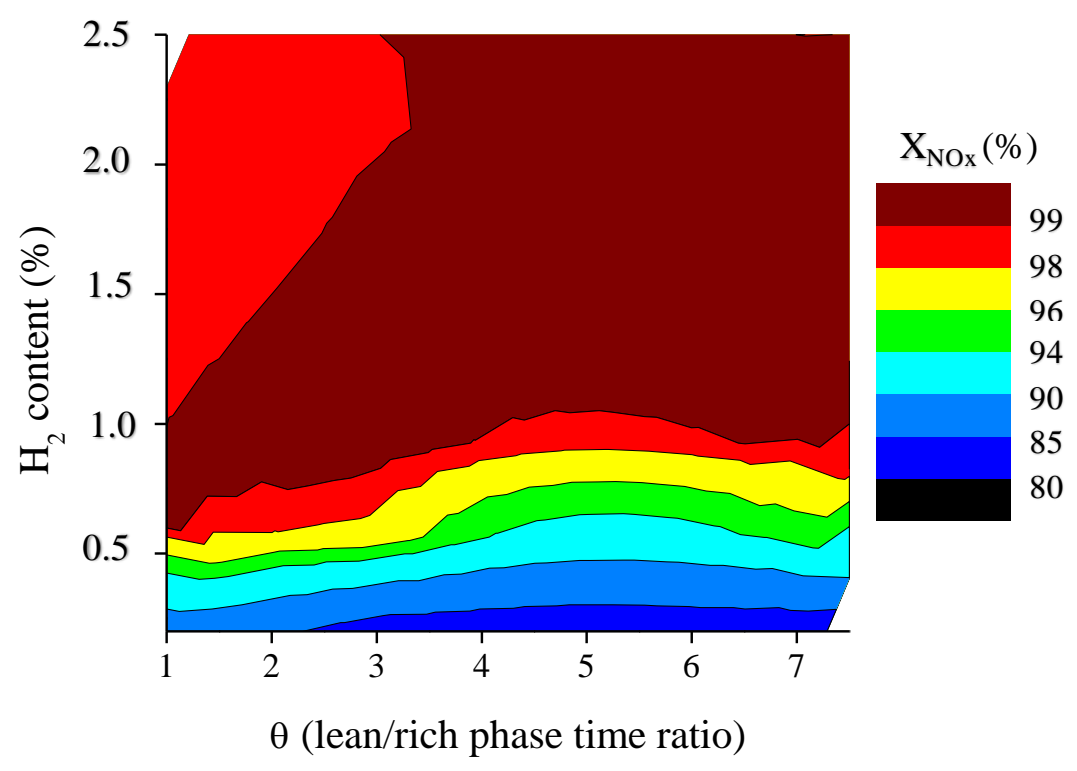

Figure 6. $\mathrm{NO}_{\mathrm{x}}$ Iso-conversion profile according to the operation parameters for $\mathrm{Pt}-\mathrm{Ba}-\mathrm{K} / \mathrm{Al}_{2} \mathrm{O}_{3}+$ 2Cu-SAPO-34 system in $\mathrm{H}_{2} \mathrm{O}+\mathrm{CO}_{2}$ atmosphere at $350{ }^{\circ} \mathrm{C}$.

As explained above, the increment in the hydrogen content increases the conversion and removal of nitrogen oxides, even though the hydrogen content should not be in excess, which produces unnecessary cost and unburned hydrocarbon emission. At low time ratios, with hydrogen content above the stoichiometric value, more than $90 \%$ of $\mathrm{NO}_{\mathrm{x}}$ conversion is achieved. When increasing the $\theta$ value, an ascendant trend with a low slope can be observed because the increment of the $\mathrm{NO}_{\mathrm{x}}$ adsorbed required a higher amount of reductant agent to regenerate the surface and convert the $\mathrm{NO}_{\mathrm{x}}$. Yet, high conversion values are obtained in all the operation ranges. These formulations, keeping a $\mathrm{V}_{\mathrm{NSR}} / \mathrm{V}_{\mathrm{SCR}}=1 / 1$, are suitable to incorporate into a cordierite monolithic structure (400 cpsi), with an $\mathrm{Al}_{2} \mathrm{O}_{3}$ wash-coating $(12-15 \mu \mathrm{m})$, as layers below $5 \mu \mathrm{m}$ of LNT or SCR catalysts. The macroscope cubic structure of Cu-SAPO-34 material limits the thickness of the layer to keep the homogenous structure along the channel. Therefore, the hybrid system can operate in a bench engine.

\section{Materials and Methods}

\subsection{Synthesis of Catalysts}

Pt-Ba-K/ $/ \mathrm{Al}_{2} \mathrm{O}_{3}$ was employed as an NSR catalyst due to its excellent properties in $\mathrm{NO}_{\mathrm{x}}$ and soot removal. The multi-metallic supported catalyst was prepared by co-impregnation with the following metal contents 0.4 at- $\mathrm{Pt}, 3.5$ at- $\mathrm{Ba}$, and 1.5 at $-\mathrm{K} \cdot \mathrm{nm}^{-2}$ using $\gamma-\mathrm{Al}_{2} \mathrm{O}_{3} \mathrm{TH}$, with $144 \mathrm{~m}^{2} \cdot \mathrm{g}^{-1}$ of surface area, which is equivalent to $1.9,11.5$, and $1.4 \mathrm{wt} . \%$ of $\mathrm{Pt}, \mathrm{Ba}$, and $\mathrm{K}$, respectively, with the same procedure described in Reference [35] where an optimization of the metal loading compared to the standard Pt-Ba model catalyst was demonstrated. Cu-SAPO-34 was used as an SCR catalytic bed because of the combination of its catalytic activity and structural properties $[30,46]$. The catalyst was synthesized by a hydrothermal method assisted by ultrasound with $2 \mathrm{wt}$. \% of copper in the molar gel composition: $2 \mathrm{DEA}$ (diethylamine): $0.6 \mathrm{SiO}_{2}: 1 \mathrm{Al}_{2} \mathrm{O}_{3}: 0.2 \mathrm{P}_{2} \mathrm{O}_{5}: 50 \mathrm{H}_{2} \mathrm{O}$. The synthesis procedure of these materials and their characterization and activity in the individualized technologies have been previously reported $[30,35,51]$.

\subsection{Catalytic Activity}

Experiments were carried out in a quartz U-tube reactor connected to the QMS 200 Mass Spectrometer (Pfeiffer Vacuum Prisma ${ }^{\mathrm{TM}}$, Málaga, Spain) and the Gas Chromatograph $\mu$-GC 3000A (Agilent, Santa Clara, CA, USA) with a data sampling interval of $4 \mathrm{~s}$ and $3 \mathrm{~min}$, respectively. The 
zeolitic material was placed downstream in the reactor and both catalytic beds were separated by a quartz wool layer. The total gas flow was $100 \mathrm{~cm}^{3} \cdot \mathrm{min}^{-1}$ using $60 \mathrm{mg}$ of each catalytic bed in powder form, where the catalysts were mixed with quartz in order to obtain different ratios. Experiments were performed alternating lean-rich cycles as a TRM (Transient Response Method) procedure with $1000 \mathrm{ppm}$ of $\mathrm{NO}+3 \%$ of $\mathrm{O}_{2}$ and $2000 \mathrm{ppm}$ of hydrogen as a reductant up to saturation and complete regeneration, i.e., $15 \mathrm{~min}$ for each phase for the experiments in stoichiometric conditions. The hydrogen content and the time of each period were also modified. In Table 2, the reaction conditions used in the experiments are summarized.

As can be observed, although the LNT cyclic procedure was used, some parameters varied in order to study their effect, such as: the catalytic-bed volume ratio $\left(\mathrm{V}_{\mathrm{NSR}} / \mathrm{V}_{\mathrm{SCR}}=1 / 0,1 / 1\right.$ and $\left.1 / 0.5\right)$, the hydrogen content as a reductant agent $(0.2,1,2.5 \%(\mathrm{v} / \mathrm{v}))$, the oxidant/reductant phases time ratio $(\theta=1,3,7.5)$, and the impact of $\mathrm{H}_{2} \mathrm{O}+\mathrm{CO}_{2}$ atmosphere. The Gas Hourly Space Velocity (GHSV) was maintained at $3 \cdot 10^{4} \mathrm{~h}^{-1}$ with respect to each catalytic bed in order to obtain data that were comparable to those reported for the single bed. The amount of $\mathrm{NO}_{\mathrm{x}}$ removed per gram of catalyst was calculated as the difference in area between the inlet and the outlet in the lean phase, which is multiplied by the corresponding ratio between total flow $(\mathrm{F})$ and molar volume $\left(\mathrm{V}_{\mathrm{m}}\right)$ (Equation (1)).

$$
\frac{m m o l \text { NOx removed }}{g_{\text {cat }}}=\frac{\left(A_{N O x}^{\text {in }}-A_{N O x}^{\text {out }}\right)_{\text {lean }} \cdot \frac{F}{V_{m}}}{w_{\text {cat }}}
$$

The $\mathrm{NO}_{\mathrm{x}}$ conversion was calculated as the difference between the removed amount and the $\mathrm{NO}_{\mathrm{x}}$ at the outlet in the rich phase divided by the $\mathrm{NO}_{\mathrm{x}}$ removed (Equation (2)).

$$
X_{N O x}=\frac{\left(A_{N O x}^{\text {in }}-A_{N O x}^{\text {out }}\right)_{\text {lean }}-\left(A_{N O x}^{\text {out }}\right)_{\text {rich }}}{\left(A_{N O x}^{\text {in }}-A_{N O x}^{\text {out }}\right)_{\text {lean }}}
$$

\section{Conclusions}

In this study, the application of a combined LNT-SCR dual-bed catalytic system to improve $\mathrm{NO}_{\mathrm{x}}$ reduction efficiency together with the potential in deNOxing performance under simulated diesel exhaust conditions were demonstrated. This opens the way toward the use of a hybrid after-treatment catalytic system to reach zero $\mathrm{NO}_{\mathrm{x}}$-emission. Volume ratio of LNT and SCR catalysts and the operation parameters (reductant content and lean/rich time ratio) were established for the efficient and enhanced formulations of catalysts Pt-K-Ba/ $\mathrm{Al}_{2} \mathrm{O}_{3}+\mathrm{Cu}-\mathrm{SAPO}-34$.

The NSR-SCR hybrid system, with a volumetric ratio 1:1 working with $\theta$ values lower than 3 and a hydrogen content as a reducing agent between 2000 and 10,000 ppm, favored high levels of mineralization to nitrogen, complete regeneration of catalysts after the rich phase, and hindered the detection of $\mathrm{N}$-intermediates as $\mathrm{N}_{2} \mathrm{O}$ or $\mathrm{NH}_{3}$ during the nearly 50 cycles by working with conversion average values close to $95 \%$.

Author Contributions: Experiment, M.C.-R.; Writing—Review \& Editing, M.C.R., M.Á.L., C.H. and L.J.A.; Project Administration, L.J.A. and C.H.; Financial Support Acquisition, M.Á.L., C.H. and L.J.A. All authors have read and agreed to the published version of the manuscript.

Funding: This research received no external funding.

Acknowledgments: MCR acknowledges the Spanish Ministry of Education, Culture and Sport (FPU12/03826) for the FPU Grant and Universidad de Málaga. Authors want to thank the financial support of the CTQ 2017-87909R project.

Conflicts of Interest: The authors declare no conflict of interest. 


\section{References}

1. Cortés-Reyes, M.; Herrera, C.; Larrubia, M.A.; Auñón, J.A.; González, M.; Alemany, L.J. Impact of new biofuels on pollutant production and motor performance and study of DeNOx technologies to achieve zero emission in real conditions. Int. J. Innov. Res. Sci. Eng. Technol. 2016, 5, 13082-13088.

2. Kočí, P.; Plát, F.; Štěpánek, J.; Bártová, Š.; Marek, M.; Kubíček, M.; Schmeißer, V.; Chatterjee, D.; Weibel, M. Global kinetic model for the regeneration of NOx storage catalyst with $\mathrm{CO}, \mathrm{H}_{2}$ and $\mathrm{C}_{3} \mathrm{H}_{6}$ in the presence of $\mathrm{CO}_{2}$ and $\mathrm{H}_{2} \mathrm{O}$. Catal. Today 2009, 147, S257-S264. [CrossRef]

3. Ting, A.W.-L.; Li, M.; Harold, M.P.; Balakotaiah, V. Fast cycling in a non-isothermal monolithic lean NOx trap using $\mathrm{H}_{2}$ as reductant: Experiments and modeling. Chem. Eng. J. 2017, 326, 419-435. [CrossRef]

4. Cortés-Reyes, M.; Herrera, C.; Larrubia, M.Á.; Alemany, L.J. Advance in the scaling up of a hybrid catalyst for NSR-SCR coupled systems under $\mathrm{H}_{2} \mathrm{O}+\mathrm{CO}_{2}$ atmosphere. Catal. Today 2019. [CrossRef]

5. Kubiak, L.; Castoldi, L.; Lietti, L.; Andonova, S.; Olsson, L. Mechanistic investigation of the reduction of NOx over Pt- and Rh-Based LNT Catalysts. Catalysts 2016, 6, 46. [CrossRef]

6. Krishna, K.; Makkee, M. Soot oxidation over NOx storage catalysts: Activity and deactivation. Catal. Today 2006, 114, 48-56. [CrossRef]

7. Gálvez, M.E.; Ascaso, S.; Tobías, I.; Moliner, R.; Lázaro, M.J. Catalytic filters for the simultaneous removal of soot and NOx: Influence of the alumina precursor on monolith washcoating and catalytic activity. Catal. Today 2012, 191, 96-105. [CrossRef]

8. De La Torre, U.; Pereda-Ayo, B.; Romero-Sáez, M.; Aranzabal, A.; González-Marcos, M.P.; González-Marcos, J.A.; González-Velasco, J.R. Screening of Fe-Cu-zeolites prepared by different methodology for application in NSR-SCR combined DeNOxsystems. Top. Catal. 2013, 56, 215-221. [CrossRef]

9. Olsson, L.; Wijayanti, K.; Leistner, K.; Kumar, A.; Joshi, S.Y.; Kamasamudram, K.; Currier, N.W.; Yezerets, A. A kinetic model for sulfur poisoning and regeneration of Cu/SSZ-13 used for NH3-SCR. Appl. Catal. B Environ. 2016, 183, 394-406. [CrossRef]

10. Xu, L.; McCabe, R.W. LNT+in situ SCR catalyst system for diesel emissions control. Catal. Today 2012, 184, 83-94. [CrossRef]

11. Pereda-Ayo, B.; Duraiswami, D.; González-Velasco, J.R. Control of NOx storage and reduction in NSR bed for designing combined NSR-SCR systems. Catal. Today 2011, 172, 66-72. [CrossRef]

12. De La Torre, U.; Pereda-Ayo, B.; González-Velasco, J.R. Cu-zeolite NH3-SCR catalysts for NOx removal in the combined NSR-SCR technology. Chem. Eng. J. 2012, 207-208, 10-17. [CrossRef]

13. Castoldi, L.; Bonzi, R.; Lietti, L.; Forzatti, P.; Morandi, S.; Ghiotti, G.; Dzwigaj, S. Catalytic behaviour of hybrid LNT/SCR systems: Reactivity and in situ FTIR study. J. Catal. 2011, 282, 128-144. [CrossRef]

14. Lindholm, A.; Sjövall, H.; Olsson, L. Reduction of NOx over a combined NSR and SCR system. Appl. Catal. B Environ. 2010, 98, 112-121. [CrossRef]

15. Forzatti, P.; Lietti, L.; Nova, I.; Tronconi, E. Diesel NOx aftertreatment catalytic technologies: Analogies in LNT and SCR catalytic chemistry. Catal. Today 2010, 151, 202-211. [CrossRef]

16. Can, F.; Courtois, X.; Royer, S.; Blanchard, G.; Rousseau, S.; Duprez, D. An overview of the production and use of ammonia in NSR+SCR coupled system for NOx reduction from lean exhaust gas. Catal. Today 2012, 197, 144-154. [CrossRef]

17. Harold, M.P. NOx storage and reduction in lean burn vehicle emission control: A catalytic engineer's playground. Curr. Opin. Chem. Eng. 2012, 1, 303-311. [CrossRef]

18. Lietti, L.; Artioli, N.; Righini, L.; Castoldi, L.; Forzatti, P. Pathways for $\mathrm{N}_{2}$ and $\mathrm{N}_{2} \mathrm{O}$ formation during the reduction of $\mathrm{NOx}$ over $\mathrm{Pt}-\mathrm{Ba} / \mathrm{Al} 2 \mathrm{O} 3 \mathrm{LNT}$ catalysts investigated by labeling isotopic experiments. Ind. Eng. Chem. Res. 2012, 51, 7597-7605. [CrossRef]

19. Bonzi, R.; Lietti, L.; Castoldi, L.; Forzatti, P. NOx removal over a double-bed NSR-SCR reactor configuration. Catal. Today 2010, 151, 376-385. [CrossRef]

20. Forzatti, P.; Lietti, L. The reduction of NOx stored on LNT and combined LNT-SCR systems. Catal. Today 2010, 155, 131-139. [CrossRef]

21. Corbos, E.C.; Haneda, M.; Courtois, X.; Marecot, P.; Duprez, D.; Hamada, H. Cooperative effect of Pt-Rh/Ba/Al and CuZSM-5 catalysts for NOx reduction during periodic lean-rich atmosphere. Catal. Commun. 2008, 10, 137-141. [CrossRef] 
22. Corbos, E.C.; Haneda, M.; Courtois, X.; Marecot, P.; Duprez, D.; Hamada, H. NOx abatement for lean-burn engines under lean-rich atmosphere over mixed NSR-SCR catalysts: Influences of the addition of a SCR catalyst and of the operational conditions. Appl. Catal. A Gen. 2009, 365, 187-193. [CrossRef]

23. De La Torre, U.; Urrutxua, M.; Pereda-Ayo, B.; González-Velasco, J.R. On the Cu species in Cu/beta catalysts related to DeNOx performance of coupled NSR-SCR technology using sequential monoliths and dual-layer monolithic catalysts. Catal. Today 2016, 273, 72-82. [CrossRef]

24. Can, F.; Courtois, X.; Berland, S.; Seneque, M.; Royer, S.; Duprez, D. Composition dependent performance of alumina-based oxide supported WO3 catalysts for the NH3-SCR reaction and the NSR + SCR coupled process. Catal. Today 2015, 257, 41-50. [CrossRef]

25. Colombo, M.; Nova, I.; Tronconi, E. A comparative study of the NH3-SCR reactions over a Cu-zeolite and a Fe-zeolite catalyst. Catal. Today 2010, 151, 223-230. [CrossRef]

26. Martínez-Franco, R.; Moliner, M.; Franch, C.; Kustov, A.; Corma, A. Rational direct synthesis methodology of very active and hydrothermally stable Cu-SAPO-34 molecular sieves for the SCR of NOx. Appl. Catal. B Environ. 2012, 127, 273-280. [CrossRef]

27. De La Torre, U.; Pereda-Ayo, B.; Moliner, M.; González-Velasco, J.R.; Corma, A. Cu-zeolite catalysts for NOx removal by selective catalytic reduction with $\mathrm{NH} 3$ and coupled to $\mathrm{NO}$ storage/reduction monolith in diesel engine exhaust aftertreatment systems. Appl. Catal. B Environ. 2016, 187, 419-427. [CrossRef]

28. Yu, L.; Zhong, Q.; Zhang, S. Research of copper contained SAPO-34 zeolite for NH3-SCR DeNOx by solvent-free synthesis with Cu-TEPA. Microporous Mesoporous Mater. 2016, 234, 303-309. [CrossRef]

29. Ma, L.; Cheng, Y.; Cavataio, G.; McCabe, R.W.; Fu, L.; Li, J. Characterization of commercial Cu-SSZ-13 and Cu-SAPO-34 catalysts with hydrothermal treatment for NH3-SCR of NOx in diesel exhaust. Chem. Eng. J. 2013, 225, 323-330. [CrossRef]

30. Cortés-Reyes, M.; Finocchio, E.; Herrera, C.; Larrubia, M.A.; Alemany, L.J.; Busca, G. A study of Cu-SAPO-34 catalysts for SCR of NOx by ammonia. Microporous Mesoporous Mater. 2017, 241, 258-265. [CrossRef]

31. Ting, A.W.-L.; Harold, M.P.; Balakotaiah, V. Elucidating the mechanism of fast cycling NOx storage and reduction using $\mathrm{C}_{3} \mathrm{H}_{6}$ and $\mathrm{H}_{2}$ as reductants. Chem. Eng. Sci. 2018, 189, 413-421. [CrossRef]

32. De-La-Torre, U.; Pereda-Ayo, B.; Moliner, M.; González-Marcos, J.A.; Corma, A.; González-Velasco, J.R. Optimal operating conditions of coupled sequential NOx storage/reduction and $\mathrm{Cu} / \mathrm{CHA}$ selective catalytic reduction monoliths. Top. Catal. 2017, 60, 30-39. [CrossRef]

33. Kota, A.S.; Luss, D.; Balakotaiah, V. Modeling studies on lean NOx reduction by a sequence of LNT-SCR bricks. Ind. Eng. Chem. Res. 2012, 51, 6686-6696. [CrossRef]

34. Al-Harbi, M.; Epling, W.S. Effects of different regeneration timing protocols on the performance of a model NOx storage/reduction catalyst. Catal. Today 2010, 151, 347-353. [CrossRef]

35. Cortés-Reyes, M.; Herrera, M.C.; Pieta, I.S.; Larrubia, M.A.; Alemany, L.J. In situ TG-MS study of NOx and soot removal over LNT model catalysts. Appl. Catal. A Gen. 2016, 523, 193-199. [CrossRef]

36. Righini, L.; Kubiak, L.; Morandi, S.; Castoldi, L.; Lietti, L.; Forzatti, P. n-Heptane As a Reducing Agent in the NOx Removal over a Pt-Ba/ $\mathrm{Al}_{2} \mathrm{O}_{3}$ NSR Catalyst. ACS Catal. 2014, 4, 3261-3272. [CrossRef]

37. Seo, C.-K.; Kim, H.; Choi, B.; Lim, M.T. The optimal volume of a combined system of LNT and SCR catalysts. J. Ind. Eng. Chem. 2011, 17, 382-385. [CrossRef]

38. Adamski, A.; Zając, W.; Zasada, F.; Sojka, Z. Copper ionic pairs as possible active sites in $\mathrm{N}_{2} \mathrm{O}$ decomposition on $\mathrm{CuO}_{x} / \mathrm{CeO}_{2}$ catalysts. Catal. Today 2012, 191, 129-133. [CrossRef]

39. Zabilskiy, M.; Djinović, P.; Erjavec, B.; Dražić, G.; Pintar, A. Small CuO clusters on $\mathrm{CeO}_{2}$ nanospheres as active species for catalytic $\mathrm{N}_{2} \mathrm{O}$ decomposition. Appl. Catal. B Environ. 2015, 163, 113-122. [CrossRef]

40. Palella, B.I.; Cadoni, M.; Frache, A.; Pastore, H.O.; Pirone, R.; Russo, G.; Coluccia, S.; Marchese, L. On the hydrothermal stability of CuAPSO-34 microporous catalysts for $\mathrm{N}_{2} \mathrm{O}$ decomposition: A comparison with CuZSM-5. J. Catal. 2003, 217, 100-106. [CrossRef]

41. Smeets, P.J.; Sels, B.F.; van Teeffelen, R.M.; Leeman, H.; Hensen, E.J.M.; Schoonheydt, R.A. The catalytic performance of $\mathrm{Cu}$-containing zeolites in $\mathrm{N}_{2} \mathrm{O}$ decomposition and the influence of $\mathrm{O}_{2}, \mathrm{NO}$ and $\mathrm{H}_{2} \mathrm{O}$ on recombination of oxygen. J. Catal. 2008, 256, 183-191. [CrossRef]

42. Hendershot, R.J.; Vijay, R.; Snively, C.M.; Lauterbach, J. High-throughput study of the influence of $\mathrm{H}_{2} \mathrm{O}$ and $\mathrm{CO}_{2}$ on the performance of nitrogen storage and reduction (NSR) catalysts. Appl. Surf. Sci. 2006, 252, 2588-2592. [CrossRef] 
43. Lietti, L.; Nova, I.; Forzatti, P. Role of ammonia in the reduction by hydrogen of NOx stored over Pt-Ba/Al $\mathrm{O}_{3}$ lean NOx trap catalysts. J. Catal. 2008, 257, 270-282. [CrossRef]

44. Pieta, I.S.; García-Diéguez, M.; Herrera, C.; Larrubia, M.A.; Alemany, L.J. In situ DRIFT-TRM study of simultaneous NOx and soot removal over Pt-Ba and Pt-K NSR catalysts. J. Catal. 2010, 270, $256-267$. [CrossRef]

45. Luo, J.Y.; Epling, W.S. New insights into the promoting effect of $\mathrm{H}_{2} \mathrm{O}$ on a model $\mathrm{Pt} / \mathrm{Ba} / \mathrm{Al}_{2} \mathrm{O}_{3}$ NSR catalyst. Appl. Catal. B Environ. 2010, 97, 236-247. [CrossRef]

46. Cortés-Reyes, M.; Larrubia, M.Á.; Herrera, C.; Alemany, L.J. Influence of $\mathrm{CO}_{2}$ and $\mathrm{H}_{2} \mathrm{O}$ co-feeding in the NOx abatement by SCR over an efficient Cu-CHA catalyst. Chem. Eng. Sci. 2019, 201, 373-381. [CrossRef]

47. Ren, Y.; Harold, M.P. NOx storage and reduction with $\mathrm{H}_{2}$ on $\mathrm{Pt} / \mathrm{Rh} / \mathrm{BaO} / \mathrm{CeO}_{2}$ : Effects of $\mathrm{Rh}$ and $\mathrm{CeO}_{2}$ in the absence and presence of $\mathrm{CO}_{2}$ and $\mathrm{H}_{2} \mathrm{O}$. ACS Catal. 2011, 1, 969-988. [CrossRef]

48. Chatterjee, D.; Kočí, P.; Schmeißer, V.; Marek, M.; Weibel, M.; Krutzsch, B. Modelling of a combined NOx storage and NH3-SCR catalytic system for Diesel exhaust gas aftertreatment. Catal. Today 2010, 151, 395-409. [CrossRef]

49. Bártová, Š.; Kočí, P.; Mráček, D.; Marek, M.; Pihl, J.A.; Choi, J.-S.; Toops, T.J.; Partridge, W.P. New insights on $\mathrm{N}_{2} \mathrm{O}$ formation pathways during lean/rich cycling of a commercial lean NOx trap catalyst. Catal. Today 2014, 231, 145-154. [CrossRef]

50. Shakya, B.M.; Harold, M.P.; Balakotaiah, V. Modeling and analysis of dual-layer NOx storage and reduction and selective catalytic reduction monolithic catalyst. Chem. Eng. J. 2014, 237, 109-122. [CrossRef]

51. Cortés-Reyes, M.; Herrera, M.C.; Larrubia, M.A.; Alemany, L.J. Fast ultrasound assisted synthesis of Cu-SAPO-34 for SCR application. Int. J. Innov. Res. Sci. Eng. Technol. 2016, 5, 5540-5550.

(C) 2020 by the authors. Licensee MDPI, Basel, Switzerland. This article is an open access article distributed under the terms and conditions of the Creative Commons Attribution (CC BY) license (http://creativecommons.org/licenses/by/4.0/). 